\title{
Lifestyle and risk behaviors for chronic noncommunicable diseases among healthcare undergraduates in Midwest, Brazil
}

\author{
Estilo de vida e comportamentos de risco para doenças crônicas \\ não transmissíveis entre universitários da saúde na região \\ Centro-Oeste, Brasil
}

Luciana Zaranza Monteiro (http://orcid.org/0000-0001-7484-1185)

Andrea Ramirez Varela (http://orcid.org/0000-0003-2685-9617)2

Bruno Alves de Lira (http://orcid.org/0000-0003-3856-8438) ${ }^{1}$

Suliane Beatriz Rauber (http://orcid.org/0000-0003-3091-8464) ${ }^{1}$

Juliana Oliveira de Toledo (http://orcid.org/0000-0002-5065-2870) ${ }^{3}$

Milenne da Silva Spinola (http://orcid.org/0000-0001-9769-4325) ${ }^{4}$

Maria de Lourdes Alves Carneiro (http://orcid.org/0000-0001-9393-2832) ${ }^{3}$

Francelino Braga Junior (http://orcid.org/0000-0003-0067-1974) ${ }^{1}$

${ }^{1}$ Departamento de

Educação Física, Centro

Universitário do Distrito

Federal. Sgas 903 s/n LT52,

Edhob. 70390-045 Brasília

DF Brasil. lucianazaranza@

hotmail.com

${ }^{2}$ Centro de Pesquisa

em Epidemiologia,

Universidade Federal de

Pelotas. Pelotas RS Brasil.

${ }^{3}$ Departamento de

Farmácia, Centro

Universitário do Distrito

Federal. Brasília DF Brasil.

${ }^{4}$ Departamento de

Enfermagem, Centro

Universitário do Distrito

Federal. Brasília DF Brasil.

\begin{abstract}
This study aimed to assess the lifestyle of undergraduate university students, and to investigate the prevalence of risk behaviors for chronic noncommunicable diseases. This cross-sectional study took place in Brasilia, with 2.163 healthcare undergraduates. We used a self-administered questionnaire for demographic variables, social class, behavioral data, self-perception of health and self-reported diseases. Given a total of 2.163 students, $69.3 \%$ were female, 65.4\% were 20-29 years, men smoked more cigarettes $(p<0.01)$ and used more alcohol than women. We found significant differences in the consumption of beans ( $p<$ $0.04)$ and full-fat milk $(p<0.01)$ between females and males. Women also had more sedentary lifestyles $(p<0.01)$ and showed higher prevalences of overweight (33.8\%) and obesity (5.0\%). Students who did not engage in physical activity were more morbidities, overweight $(p=0.03)$, consumed more soft drinks $(p<0.01)$ and meat with excess fat $(p=0.01)$. University students were found to have unhealthy lifestyles. There is an urgent need for both a formulation and implementation of public health policies to promote health and improve student quality of life (QoL).

Key words University students, Lifestyle, Chronic diseases, Prevention
\end{abstract}

Resumo Este estudo teve como objetivo avaliar o estilo de vida dos universitários e investigar a prevalência de comportamentos de risco para doenças crônicas não transmissíveis. Estudo transversal com 2.163 universitários da área de saúde da cidade de Brasília. Foi aplicado um questionário sobre as variáveis demográficas, classe social, comportamentos e autopercepção de saúde e doenças autorreferidas. Dos 2.163, 69,3\% eram mulheres, 65,4\% idade entre 20 a 29 anos, 66,8\% consumiam álcool e 44,2\% não realizavam atividade física. Os homens fumavam $(p<0,01)$ e consumiam mais álcool do que as mulheres. Encontramos diferenças no consumo de feijão $(p<0,04)$ e leite integral $(p<0,01)$ entre homens e mulheres. Elas também apresentaram estilos de vida mais sedentários $(p<0,01)$ e elevada prevalência de sobrepeso $(33,8 \%)$ e obesidade (5,0\%). Os estudantes que não praticavam atividade física tinham mais morbidades, estavam acima do peso $(p=0,03)$, consumiam mais refrigerantes $(p<0,01)$ e carne com excesso de gordura $(p=0,01)$. Os estudantes têm adotado um estilo de vida pouco saudável. Observa-se a necessidade da elaboração e implantação de políticas públicas de promoção da saúde dentro da Universidade, com vistas à melhoria da saúde e da qualidade de vida dos universitários. Palavras-chave Universitários, Estilo de vida, Doenças crônicas, Prevenção 


\section{Introduction}

An exponential increase in the global burden of chronic noncommunicable diseases (NCDs) marked the beginning of the twenty-first century. Population aging, improved survival opportunities and the rapid rise in obesogenic environments were the potential contributors ${ }^{1}$. NCDs are characterized by having multiple causes and a gradual onset, occurring over an extensive period of time, and leading to irreversible lesions, disability and death ${ }^{2}$. In Brazil, $70 \%$ of deaths are caused by NCDs, and it is estimated that, by 2025, 15 million people will die from NCDs ${ }^{3}$.

Risk factors for the development of NCDs are classified as modifiable and non-modifiable ${ }^{4}$. Modifiable risk behaviors are smoking, alcohol use, overweight, dyslipidemias, low intake of fruit, vegetables and greens, and physical inactivity $^{5}$. Non-modifiable risk factors are heredity, race/ethnicity and gender ${ }^{6}$.

Global lifestyle changes, especially poor dietary habits, physical inactivity, and smoking, are the results of industrialization, urbanization, and the development and increasing globalization of food markets, and together have produced an increase in chronic diseases ${ }^{7}$.

Admission to higher education brings changes to the lifestyle habits of young people, especially when they are away from home (which is the case most of the time). Such young people develop a foundation of unhealthy behaviors that might last throughout their lives and could compromise their present and future health ${ }^{8}$.

The impact of lifestyle behaviors on people's health has become a topic of intense interest, as low levels of health and well-being are associated with negative consequences, especially among young university students, who constitute a vulnerable group. This is because young adults start questioning the values, beliefs, and attitudes that they learned from their families when they enter college?.

This questioning might result in new behaviors and impact the way they perceive their health ${ }^{10}$. Adolescence and young adulthood are inherently marked by biological, psychological, and social instabilities. The university environment fosters new social relations and the adoption of new behaviors, making students more vulnerable to health risk behaviors ${ }^{11}$.

The growing interest in the topic of lifestyle habits is related to the widespread concern about the improvement of living conditions through actions that promote adherence to healthy lifestyle behaviors.
Investigating lifestyle and risk behaviors for NCDs is essential to verify the need for public health policies that target university campuses, thereby promoting healthier lifestyles among students.

This study aimed to assess the lifestyle of undergraduate university students, and to investigate the prevalence of risk behaviors for chronic noncommunicable diseases.

\section{Methods}

This cross-sectional study was conducted with healthcare (Nursing, Physical Education and Pharmacy) undergraduate students of a private institution in Brasília, Brazil.

The study population was composed of first to eighth-semester students who were in their classrooms on the day of data collection.

A convenience sample consisted of 2,163 undergraduate students (who were 18 or older) out of the total of 2,468 students enrolled in the program during the academic year of 2016 were included in the study. The loss of 305 students representing $12.4 \%$ of the population is because students did not attend to the university in the day of data collection. A second attempt to include the students that missed the first day of data collection was made during another day. If the student missed both opportunities, he/she was not included in the study.

The number of participants was defined based on the guidelines on simple random sampling provided by Luiz and Magnanini ${ }^{12}$. The number of students per course was taken into consideration for sample size calculation. The maximum tolerable error rate was $5 \%$ and the $95 \%$ confidence levels were indicated. We assumed a $50 \%$ prevalence for the outcome. Thus, the final sample consisted of 974 undergraduate Nursing students, 903 undergraduate Physical Education students, and 286 undergraduate Pharmacy students.

Data collection was performed between October 2016 and May 2017 by trained researchers. The instrument was administered during the break between lessons, in a classroom with a seating capacity for 60 students. The completed questionnaire was placed in an envelope containing the group name and the course session (morning, afternoon or evening), and handed back to the researchers.

Before distributing the instrument for self-completion and the informed consent form for signing, the researchers briefly introduced 
themselves and explained the aims and methods of the study to the professor in charge of that particular class. Next, the researchers introduced themselves and the study project to the students and invited them to participate.

\section{Measures and procedures}

We used a self-administered questionnaire on health-related life habits. All questions were obtained from the Surveillance of Risk and Protective Factors for Chronic Diseases through Telephone Interviews ${ }^{13}$. The questionnaire monitored the main risk and protective factors for non-communicable chronic diseases (NCD) among adults older than age 18 and is applied on an annual and continuous basis in all Brazilian states and the Federal District ${ }^{13}$.

The following demographic variables were included in the analysis: gender (male or female); age group ( $\leq 19,20-29$ e $\geq 30)$; undergraduate course, semester of course, socioeconomic level - A, B, C e D (based on the questionnaire of the ABEP - Brazilian Association of Research Companies) ${ }^{14}$; heavy drinking (yes/no) (heavy drinking was defined as the consumption of five or more drinks in one sitting for men and four or more drinks in one sitting for women); smoking (yes/no); and health self-perception (excellent, very good, good, fair or poor), self-reported history of diseases (hypertension, diabetes, high cholesterol, dyslipidemia).

Specific questions were asked about the regularity and frequency of consumption of the following food items: fruit, greens/vegetables, and raw salad (on five or more days in a week - the recommended consumption frequency is five times a day or more, on five days a week or more); beans (on five or more days in a week); soft drinks (on five or more days in a week); full fat milk (on five or more days in a week); meat with excess fat (red meat with visible fat and/or chicken with skin).

In relation to nutrition questions, noncommunicable diseases protective factors were considered such as: fruit and vegetables and beans consumption at least five or more times per week. Soft drinks consumption more than five times a week and the habit of consuming whole milk and meats with visible fats were considered as risk behaviors. A healthy life score was obtained, which was the sum of protective factors for NCDs, categorized from 1 to 5 points (low) and from 6 to 10 points (Moderate/High), where the greater the number of healthy habits referred by the participant, the more points the participant had.
Level of physical activity was classified as inactive (less than 150 minutes of moderate-intensity physical activity a week or less than 75 minutes of vigorous-intensity physical activity a week accumulated across work, home, transport or discretionary domains) or active (150 or more minutes of moderate-intensity physical activity a week). $\mathrm{WHO}^{15}$ has recommended that adults aged 18-64 years should do at least $150 \mathrm{~min}$ of moderate-intensity physical activity per week.

Nutritional status was assessed by calculating body mass index (BMI) [weight in kilograms divided by the square of height in meters] Self-reported weight and height, as well as cut-off points were used in the calculation. Participants were classified as: underweight $(<18.5)$, normal weight (18.5-24.9), overweight (25-29.9) and obese $(\geq 30)^{16}$.

Data are presented as absolute and relative frequencies, and displayed with their respective 95\% confidence intervals. The association between risk factors and sex and PA was analyzed using chi-square tests.

Odds ratio were calculated using logistic regression models to analyze if gender, age and socioeconomic level are (moderate/high) healthy life score predictors. Crude and adjusted models were used in the assessment (for all variables together).

A multiple correspondence analysis was conducted to test the joint relationship between risk factors for NCDs, gender, physical activity and nutritional status. All statistical analyses were performed using the SAS Software, version 9.2, while correspondence analysis was conducted using SPSS, version 2.1. The level of significance was set at $5 \%$.

This study was approved by the Research Ethics Committee of the Centro Universitário do Distrito Federal - UDF.

\section{Results}

Given a total of 2,163 students, $69.3 \%$ were female and $65.4 \%$ were $20-29$ years. Fifty-five point one percent of participants had socioeconomic level C; 45.1\% were undergraduate Nursing students, $41.7 \%$ undergraduate Physical Education students and $13.2 \%$ undergraduate Pharmacy students; $84.4 \%$ were first- to fourth-year students.

Table 1 describes the sample according to sociodemographic, socioeconomic and health characteristics. We found that $66.8 \%$ of participants consumed alcohol; $74.4 \%$ non- smoking, 
Table 1. Description of the sample according to students's characteristics. Brasília, FD, Brazil, 2017.

\begin{tabular}{|c|c|c|}
\hline Variable & $\mathbf{n}$ & $\%$ \\
\hline \multicolumn{3}{|l|}{ Sex } \\
\hline Female & 1.500 & 69.3 \\
\hline Male & 663 & 30.7 \\
\hline \multicolumn{3}{|l|}{ Age (years) } \\
\hline$\leq 19$ & 334 & 15.4 \\
\hline $20-29$ & 1.415 & 65.4 \\
\hline$\geq 30$ & 414 & 19.2 \\
\hline \multicolumn{3}{|l|}{ Socioeconomic level } \\
\hline A & 87 & 4.0 \\
\hline $\mathrm{B}$ & 607 & 28.1 \\
\hline $\mathrm{C}$ & 1.191 & 55.1 \\
\hline $\mathrm{D}$ & 278 & 12.8 \\
\hline \multicolumn{3}{|l|}{ Undergraduate course } \\
\hline Nursing & 974 & 45.1 \\
\hline Physical Education & 903 & 41.7 \\
\hline Pharmacy & 286 & 13.2 \\
\hline \multicolumn{3}{|l|}{ Semester of course } \\
\hline 1 st to 4 th & 1.826 & 84.4 \\
\hline 5 th to 8 th & 337 & 15.6 \\
\hline \multicolumn{3}{|l|}{ Self-perception of health } \\
\hline Excellent & 296 & 13.6 \\
\hline Very good & 583 & 26.9 \\
\hline Good & 898 & 41.5 \\
\hline Fair & 338 & 15.6 \\
\hline Poor & 48 & 2.2 \\
\hline \multicolumn{3}{|l|}{ Smoking } \\
\hline Yes & 555 & 25.6 \\
\hline No & 1.608 & 74.4 \\
\hline \multicolumn{3}{|l|}{ Use of alcohol } \\
\hline Yes & 1.445 & 66.8 \\
\hline No & 718 & 33.2 \\
\hline \multicolumn{3}{|l|}{ Nutritional status } \\
\hline Underweight & 100 & 4.6 \\
\hline Normal weight & 1.227 & 56.7 \\
\hline Overweight & 735 & 33.9 \\
\hline Obese & 101 & 4.8 \\
\hline \multicolumn{3}{|l|}{$\mathrm{PA}>150 \mathrm{~min} /$ week } \\
\hline Yes & 1.207 & 55.8 \\
\hline No & 956 & 44.2 \\
\hline Total & 2.163 & 100 \\
\hline
\end{tabular}

Source: author's elaboration.
$33.9 \%$ were overweight, $44.2 \%$ did not do more than 150 minutes of PA per week; $41.5 \%$ self-assessed their health as "good", and $72.7 \%$ had studied in public schools.

Table 2 shows the estimated prevalence of protective and risk behaviors for NCDs in the total study population and according to sex. We found that $52.1 \%$ of participants had low health scores (1-5 points). Men smoked more cigarettes $(\mathrm{p}<0.01)$ and (although no significant difference was observed) used more alcohol than women.

As for dietary habits, there was a higher prevalence of protective factor behaviors in men than in women. Women only showed higher consumption of fruit. Results indicate that there is a significant difference in the consumption of beans between men and women, such that men consume more than do women $(\mathrm{p}<0.04)$.

There was a higher prevalence $(41.4 \%)$ of full fat milk consumption among women $(\mathrm{p}<0.01)$ and a higher prevalence of soft drinks consumption among men (although no significant difference was found).

We found a high prevalence of physical inactivity among undergraduate students, with significant difference between genders. Women $(48.4 \%)$ were more physically inactive than men $(\mathrm{p}<0.01)$.

There were no gender-related significant differences in self-reported diseases. However, women showed a higher prevalence of diabetes (5.6\%), high cholesterol levels (15\%) and dyslipidemia (5.5\%) than men.

Table 3 shows the association between PA (>150min/week), protective and risk factors for NCDs, and self-reported diseases in undergraduate students. Students with low levels of PA (below the current recommendation of $>150 \mathrm{~min} /$ week) were found to be underweight $(\mathrm{p}=0.03)$. Physically active participants consumed more fruit $(\mathrm{p}<0.01)$, salad $(\mathrm{p}<0.01)$ and vegetables/ greens $(\mathrm{p}<0.01)$.

There was a higher prevalence of unhealthy lifestyle behaviors in physically inactive participants, with $32.5 \%$ consuming soft drinks $(\mathrm{p}<0.01)$ and meat with visible fat $(\mathrm{p}=0.01)$.

There was a high prevalence of self-reported diseases, namely arterial hypertension $(\mathrm{p}=$ $0.02)$, diabetes $(p<0.01)$, high cholesterol levels $(\mathrm{p}<0.01)$ and dyslipidemia $(\mathrm{p}=0.02)$, in physically inactive students.

Table 4 analyzes the association between gender, age and socioeconomic level with health life score. This study found no evidence for a correlation between the aforementioned variables. 
Table 2 Prevalence of risk behaviors for NCDs among university, overall and according to sex. Brasília, FD, Brazil, 2017. N = (2.163)

\begin{tabular}{|c|c|c|c|c|c|c|c|c|c|c|}
\hline \multirow[t]{2}{*}{ Variables } & \multicolumn{3}{|c|}{ Total } & \multicolumn{3}{|c|}{ Female } & \multicolumn{3}{|c|}{ Male } & \multirow[t]{2}{*}{ p-value } \\
\hline & $\mathbf{N}$ & $\%$ & $95 \% \mathrm{CI}$ & $\mathbf{N}$ & $\%$ & $95 \% \mathrm{CI}$ & $\mathbf{N}$ & $\%$ & $95 \% \mathrm{CI}$ & \\
\hline \multicolumn{11}{|l|}{ Protective factors } \\
\hline \multicolumn{11}{|c|}{ Consumption on five or more days per week ( $\geq 5$ times/week) } \\
\hline Fruit consumption & 1.125 & 52.1 & $49.9-54.1$ & 787 & 52.4 & $49.9-55.0$ & 338 & 50.9 & $47.1-54.7$ & 0.52 \\
\hline Raw salad consumption & 916 & 42.3 & $40.2-44.4$ & 626 & 41.7 & $39.2-44.2$ & 290 & 43.7 & $39.9-47.5$ & 0.38 \\
\hline $\begin{array}{l}\text { Greens or vegetables } \\
\text { consumption }\end{array}$ & 1.133 & 52.3 & $50.2-54.4$ & 779 & 51.9 & 49.4-54.4 & 354 & 53.3 & $49.5-57.1$ & 0.53 \\
\hline Beans consumption & 1.565 & 72.3 & $70.4-74.2$ & 1.066 & 71.1 & $68.7-73.3$ & 499 & 75.3 & $71.9-78.5$ & $0.04^{\star}$ \\
\hline \multicolumn{11}{|l|}{ Risk behaviors ( $\geq 5$ times/week) } \\
\hline Soft drinks consumption & 630 & 29.1 & $27.2-31.0$ & 421 & 28.1 & $25.8-30.3$ & 209 & 31.5 & $27.9-35.0$ & 0.10 \\
\hline $\begin{array}{l}\text { Habitual intake of full-fat } \\
\text { milk }\end{array}$ & 853 & 39.4 & $37.3-41.5$ & 622 & 41.4 & $38.9-43.9$ & 231 & 34.8 & $31.2-38.4$ & $<0.01^{\star}$ \\
\hline $\begin{array}{l}\text { Habitual intake of meat } \\
\text { with visible fat }\end{array}$ & 696 & 32.1 & $30.2-34.1$ & 483 & 32.2 & $29.8-34.5$ & 213 & 32.1 & $28.5-35.6$ & 0.97 \\
\hline Physically inactive & 956 & 44.2 & $42.1-46.2$ & 727 & 48.4 & $45.9-51.0$ & 229 & 34.5 & $30.9-38.1$ & $<0.01^{\star}$ \\
\hline Smoking & 555 & 25.6 & $23.8-27.5$ & 348 & 23.2 & $21.0-25.3$ & 207 & 31.2 & $27.6-34.7$ & $<0.01^{\star}$ \\
\hline Use of alcohol & 1.445 & 66.8 & $64.8-68.7$ & 986 & 65.7 & $63.3-68.1$ & 459 & 69.2 & $65.7-72.7$ & 0.11 \\
\hline $\begin{array}{l}\text { Overweight }(\mathrm{BMI} \geq 25 \text { and } \\
\left.<30 \mathrm{~kg} / \mathrm{m}^{2}\right)\end{array}$ & 735 & 33.9 & $31.9-35.9$ & 508 & 33.8 & $31.4-36.2$ & 227 & 34.2 & $30.6-37.8$ & 0.10 \\
\hline Obesity $\left(\mathrm{BMI} \geq 30 \mathrm{~kg} / \mathrm{m}^{2}\right)$ & 101 & 4.8 & $3.7-5.5$ & 75 & 5.0 & $3.9-6.1$ & 26 & 3.9 & $2.4-5.4$ & 0.54 \\
\hline \multicolumn{11}{|l|}{ Self-reported diseases } \\
\hline Arterial hypertension & 69 & 3.1 & $2.4-3.9$ & 47 & 3.1 & $2.3-4.1$ & 22 & 3.3 & $1.9-4.68$ & 0.82 \\
\hline Diabetes mellitus & 115 & 5.3 & $4.3-6.2$ & 85 & 5.6 & $4.5-6.8$ & 30 & 4.5 & $2.9-6.1$ & 0.28 \\
\hline High cholesterol levels & 318 & 14.7 & $13.2-16.1$ & 225 & 15.0 & 13.16 .8 & 93 & 14.0 & $11.3-16.6$ & 0.56 \\
\hline Dyslipidemia & 114 & 5.2 & $4.3-6.3$ & 83 & 5.5 & $4.3-6.6$ & 31 & 4.6 & $3.1-6.2$ & 0.41 \\
\hline \multicolumn{11}{|l|}{ Health life score } \\
\hline Low & 1.125 & 52.1 & $49.9-54.1$ & 777 & 51.8 & $49.2-54.3$ & 348 & 52.4 & $48.6-56.2$ & 0.77 \\
\hline Moderate/High & 1.066 & 49.2 & $45.8-50.1$ & 723 & 48.2 & $45.6-50.7$ & 315 & 47.5 & $43.7-51.3$ & 0.82 \\
\hline
\end{tabular}

${ }^{\star}$ Chi-square test

Source: author's elaboration.

Figure 1 the joint relationship between risk behaviors for NCDs, gender, physical activity and nutritional status, as assessed by multiple correspondence analysis. For this data set, there was only $20.5 \%$ explanation in two dimensions (sum of dimensions 1 and 2).

The graph indicates that participants with high cholesterol tend to also have hypertension and dyslipidemia. Obese undergraduates were found to consume vegetables, fruit, and salad (probably due to dietary reeducation), but were physically inactive ( $<150 \mathrm{~min} / \mathrm{week})$. Underweight students consumed neither vegetables nor salad, while their overweight peers tended to have diabetes and consume soft drinks and meat with visible fat. As for the remaining factors, it was not possible to identify a specific profile, because participants showed scores close to baseline values.

The low explanation percentage obtained may be due to the large number of variables under analysis.

\section{Discussion}

This study revealed important information on the health of Brazilian undergraduate students. The study sample was mostly composed of 20-29-year-old females with low family incomes (3-5 times the Brazilian minimum wage). Four- 
Table 3. Association between healthy life habits and physical activity in undergraduate students.

\begin{tabular}{|c|c|c|c|c|c|c|c|}
\hline \multirow{3}{*}{ Variable } & \multicolumn{6}{|c|}{$\mathrm{PA}>150 \mathrm{~min} /$ week } & \multirow{3}{*}{ p-value } \\
\hline & \multicolumn{3}{|c|}{ No $(n=956)$} & \multicolumn{3}{|c|}{ Yes $(n=1207)$} & \\
\hline & $\mathbf{n}$ & $\%$ & 95\% CI & $\mathbf{n}$ & $\%$ & $95 \% \mathrm{CI}$ & \\
\hline Nutritional status & & & & & & & $0.03^{\star}$ \\
\hline Underweight & 57 & 5.96 & $4.4-7.4$ & 43 & 3.5 & $2.5-4.6$ & \\
\hline Normal weight & 519 & 54.2 & $51.1-57.4$ & 708 & 58.6 & $55.8-61.4$ & \\
\hline Overweight & 334 & 34.9 & $31.9-37.9$ & 401 & 33.2 & $30.5-35.8$ & \\
\hline Obese & 46 & 4.8 & $3.4-6.1$ & 55 & 4.5 & $3.3-5.7$ & \\
\hline \multicolumn{8}{|l|}{ Alcohol consumption } \\
\hline No & 338 & 35.3 & $32.3-38.3$ & 380 & 31.4 & $28.8-34.1$ & \\
\hline Yes & 618 & 64.6 & $61.6-67.6$ & 827 & 68.5 & $65.9-71.14$ & 0.06 \\
\hline \multicolumn{8}{|l|}{ Smoking } \\
\hline No & 708 & 74.0 & $71.2-76.8$ & 900 & 74.5 & $72.1-77.0$ & \\
\hline Yes & 248 & 25.9 & $23.1-28.7$ & 307 & 25.4 & $22.9-27.8$ & 0.79 \\
\hline \multicolumn{8}{|c|}{ Consumption of fruit ( $\geq 5$ times/week) } \\
\hline No & 541 & 56.5 & $53.4-59.7$ & 497 & 41.1 & $38.4-43.9$ & \\
\hline Yes & 415 & 43.4 & $40.2-46.5$ & 710 & 58.8 & $56.0-61.6$ & $<0.01^{\star}$ \\
\hline \multicolumn{8}{|c|}{ Consumption of salad ( $\geq 5$ times/week) } \\
\hline No & 605 & 63.2 & $60.2-66.3$ & 642 & 53.1 & $50.3-56.0$ & \\
\hline Yes & 351 & 36.7 & $33.6-39.7$ & 565 & 46.8 & $43.9-49.6$ & $<0.01^{\star}$ \\
\hline \multicolumn{8}{|c|}{ Consumption of greens ( $\geq 5$ times/week) } \\
\hline No & 523 & 54.7 & $51.5-57.8$ & 507 & 42.0 & $39.2-44.7$ & \\
\hline Yes & 433 & 45.2 & $42.1-48.4$ & 700 & 58.0 & $55.2-60.7$ & $<0.01^{\star}$ \\
\hline \multicolumn{8}{|c|}{ Consumption of beans ( $\geq 5$ times/week) } \\
\hline No & 278 & 29.0 & $26.2-31.9$ & 320 & 26.5 & $24.0-29.0$ & \\
\hline Yes & 678 & 70.9 & $68.0-73.8$ & 887 & 73.4 & $71.0-75.9$ & 0.18 \\
\hline \multicolumn{8}{|c|}{ Consumption of soft drinks ( $\geq 5$ times/week) } \\
\hline No & 645 & 67.4 & $64.5-70.4$ & 888 & 73.5 & $71.0-76.0$ & \\
\hline Yes & 311 & 32.5 & $29.5-35.5$ & 319 & 26.4 & $23.9-28.9$ & $<0.01^{\star}$ \\
\hline \multicolumn{8}{|l|}{ Consumption of full fat milk } \\
\hline No & 566 & 59.2 & $56.0-62.3$ & 744 & 61.6 & $58.9-64.3$ & \\
\hline Yes & 390 & 40.7 & $37.6-43.9$ & 463 & 38.3 & $35.6-41.1$ & 0.25 \\
\hline \multicolumn{8}{|c|}{ Consumption of meat with visible fat } \\
\hline No & 621 & 64.9 & $61.9-67.9$ & 846 & 70.0 & $67.5-72.6$ & \\
\hline Yes & 335 & 35.0 & $32.0-38.0$ & 361 & 29.9 & $27.3-32.4$ & $0.01^{*}$ \\
\hline \multicolumn{8}{|l|}{ Arterial hypertension } \\
\hline No & 916 & 95.8 & $94.5-97.0$ & 1178 & 97.6 & $96.7-98.4$ & \\
\hline Yes & 40 & 4.1 & $2.9-5.4$ & 29 & 2.4 & $1.5-3.2$ & $0.02^{*}$ \\
\hline \multicolumn{8}{|l|}{ Diabetes mellitus } \\
\hline No & 880 & 92.0 & $90.3-93.7$ & 1168 & 96.7 & $95.7-97.7$ & \\
\hline Yes & 76 & 7.9 & $6.2-9.6$ & 39 & 3.2 & $2.2-4.2$ & $<0.01^{\star}$ \\
\hline \multicolumn{8}{|l|}{ High cholesterol levels } \\
\hline No & 771 & 80.6 & $78.1-83.1$ & 1074 & 88.9 & $87.2-90.7$ & \\
\hline Yes & 185 & 19.3 & $16.8-21.8$ & 133 & 11.0 & $9.2-12.7$ & $<0.01^{\star}$ \\
\hline \multicolumn{8}{|l|}{ Dyslipidemia } \\
\hline No & 894 & 93.5 & $91.9-95.0$ & 1155 & 95.6 & $94.5-96.8$ & \\
\hline Yes & 62 & 6.4 & $4.9-8.0$ & 52 & 4.3 & $3.1-5.4$ & $0.02^{*}$ \\
\hline
\end{tabular}


Table 4. Predictive factors of moderate/high healthy life scores.

\begin{tabular}{lccccccccc}
\hline \multicolumn{1}{c}{ Likelihood modeled in Score='moderate/high } \\
\hline \multicolumn{1}{c}{ Effect } & $\begin{array}{c}\text { Crude } \\
\text { odds ratio }\end{array}$ & $\mathbf{9 5 \%}$ CI & p-value & $\begin{array}{c}\text { Adjusted } \\
\text { odds ratio }\end{array}$ & $\mathbf{9 5 \% ~ C I ~}$ & p-value \\
\hline Sex (male vs female) & 0.97 & 0.81 & 1.17 & 0.77 & 0.98 & 0.82 & 1.18 & 0.84 \\
Age (20-29 vs $\leq 19)$ & 0.88 & 0.69 & 1.11 & 0.28 & 0.88 & 0.69 & 1.11 & 0.28 \\
Age ( $\geq 30$ vs $\leq 19)$ & 0.97 & 0.73 & 1.29 & 0.83 & 0.97 & 0.73 & 1.29 & 0.83 \\
Socioeconomic level (A vs D) & 1.00 & 0.61 & 1.61 & 0.98 & 0.98 & 0.60 & 1.59 & 0.93 \\
Socioeconomic level (B vs D) & 1.11 & 0.83 & 1.47 & 0.49 & 1.10 & 0.83 & 1.46 & 0.52 \\
Socioeconomic level (C vs D) & 1.186 & 0.912 & 1.541 & 0.20 & 1.178 & 0.906 & 1.532 & 0.22 \\
\hline
\end{tabular}

Source: author's elaboration.

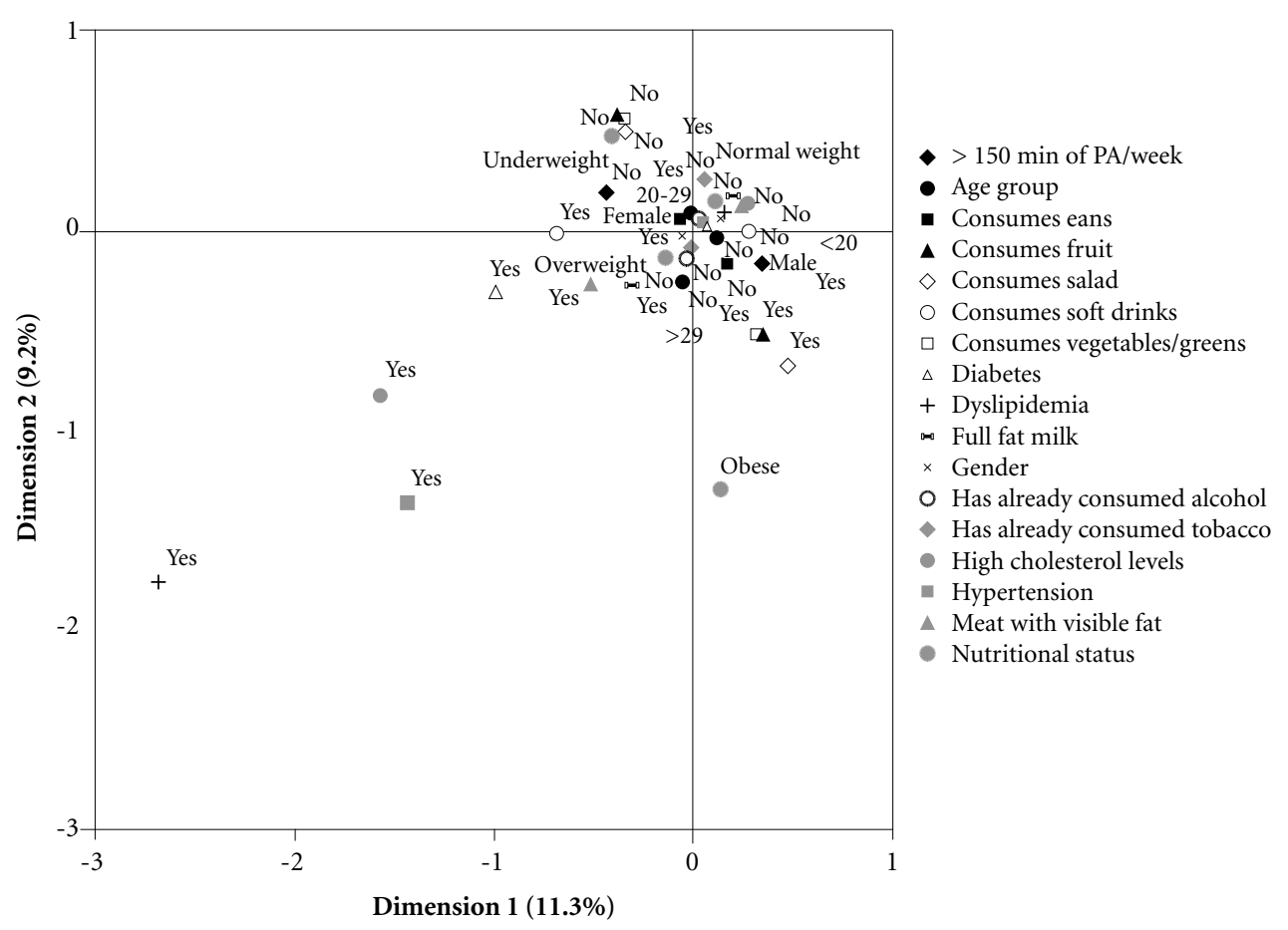

Figure 1. Joint relationship between risk factors, sex, physical activity and nutritional status of university students.

Source: author's elaboration.

teen point seven percent of the sample self-reported having high cholesterol.

A study on gender-related health behaviors among 382 final-year students in a public university in Pernambuco, Brazil, found that alcohol consumption and smoking were more prevalent in $\operatorname{men}^{17}$. The same results were found in a study conducted with undergraduate students in the fields of Biological and Exact sciences, and $\mathrm{Hu}-$ manities in the Vale do Sapucá University ${ }^{18}$. Both studies corroborate the findings of this study.

Botelho et al. ${ }^{19}$ investigated smoking prevalence among undergraduate health students from three universities in Cuiabá and Várzea Grande, MT, Brazil, and found that it ranged from 9.3\% to $21.1 \%$.

Several studies have been conducted in Brazil to elucidate the prevalence of smoking among 
undergraduates, especially those in health curriculum $s^{20}$. Seventeen percent of medical students in Severino Sombra, Brazil ${ }^{21}$ were smokers. This rate is much higher than the smoking prevalence rate reported in similar studies with undergraduates in Piauí ${ }^{22}$ and Minas Gerais ${ }^{23}$, which were as high as $7.8 \%, 6 \%$ and $6.7 \%$, respectively US and Japanese students showed prevalences of $3 \%$ and $58 \%$, respectively, while the highest smoking rates were found in Spain and Greece ${ }^{24}$.

Several studies in Brazil and globally, have shown the higher smoking prevalence among men than women ${ }^{19}$. The gender differences smoking prevalence may be explained by cultural and religious factors. Tobacco was originally introduced among men and has been associated with a symbol of masculinity and power ${ }^{20}$.

Although the alcohol consumption rate was significant in the sample as a whole, men were found to use more alcohol (69.2\%) than women $(65.7 \%)$. This confirms previous studies that demonstrate high rates of alcohol consumption among university students and similar gender-related differences in alcohol use ${ }^{25}$.

In this study, the prevalence of alcohol consumption was higher $(66.8 \%)$ than in British students $(25-42 \%)^{26}$ and medical students in Crete, Greece $(3.6 \%)^{27}$.

The majority of our sample (56.7\%) was normal weight. This agrees with the results of other studies, in which normal weight was also more prevalent among university students ${ }^{28}$.

These risk behaviors are complemented by the anthropometric profile. Men showed a higher prevalence of overweight, whereas women demonstrated a higher prevalence of obesity. This was also found by Gasparotto et al. ${ }^{9}$, who investigated risk behaviors for the development of cardiovascular diseases in 1,600 university students and found a higher incidence of overweight in men $(32 \%)$ than in women $(20 \%)$. Petrib et al..$^{29}$ corroborate conducted a study with 250 university students in Recife, Brazil. Their findings corroborate other studies in which the prevalence of overweight among women was significantly lower than that of men (5.3\% and $35.5 \%$, respectively).

Peltzer and Pengpid ${ }^{30}$ assessed nutritional status and associated factors in 15,068 university students from 21 underdeveloped and developing countries and found a prevalence of overweight and obesity of $66.1 \%$ ( $41 \%$ in men and $25.1 \%$ in women) and $27 \%$, respectively. In India, studies indicate a $37.5 \%$ prevalence of overweight among men and of $26.8 \%$ among women ${ }^{31}$.

Costa e Vasconcelos ${ }^{32}$ assessed the body weight of 220 female freshmen students of a university in
Florianópolis, SC, Brazil, and found that $72.3 \%$ of them were normal weight, $11.8 \%$ were overweight and $3.2 \%$ were obese.

The Surveillance of Risk and Protection Factors for Chronic Diseases through Telephone Interviews ${ }^{13}$ evidenced that Brazilians do not regularly consume fruit and vegetables. This agrees with the results of previous studies, which show a low prevalence of consumption of fruit and vegetables (less than five days a week) among undergraduate health students $(44 \%)^{33}$.

Overall, there was a high prevalence of physical inactivity in the sample (44.2\%), with women being more sedentary than men $(p<0.01)$. Previous studies indicate that university students are becoming increasingly inactive, and that healthcare undergraduates tend to engage in less physical activity than their peers ${ }^{34}$. This physical inactivity can be explained by the fact that women have more activities than university, such as taking care of their children, domestic work and also economic issues, thus providing less time to practice physical activity.

Florindo et al. ${ }^{35}$ demonstrated an association between level of physical activity (PA) and fruit and vegetable consumption among university students. Pinho et al. ${ }^{36}$, however, did not find such associations. This study showed a significant association between physical inactivity and lower consumption of fruits and vegetables. This fact corroborates the possible existence of concomitant behaviors that favor the occurrence of $\mathrm{NCDs}^{37}$. In this study, such behaviors are: a diet poor in fruit and vegetables, and physical inactivity. We observed that inactive students presented more morbidities and inadequate eating habits, these factors can be explained by the fact that physical inactivity provides a high prevalence of chronic diseases, as well as the appearance of metabolic and physiological alterations, such as obesity and diabetes.

Gasparotto el at. ${ }^{9}$ found that about $55 \%$ of undergraduate students in the fields of Biological and Exact sciences and Humanities undertook less than 150 minutes of physical activity per week. This evidences that only a little less than half of the sample meets the recommended levels of physical activity. In this study, a between-sex comparison demonstrated that women $(48.4 \%)$ were more sedentary than men $(p<0.01)$.

In summary, this study identified no significant differences in the number of risk behaviors for NCDs between men and women. Men had four risk behaviors (regular use of alcohol, tobacco and soft drinks, and overweight) and women also had four risk behaviors (regular consump- 
tion full fat milk and meat with visible fat, physical inactivity, and obesity).

The present study has some limitations. Firstly, the sectional design does not allow the establishment of a time relationship between the variables of interest in this research. Secondly, although risk behaviors for NCDs were assessed with a standardized and validated questionnaire, the use of self-reporting methods to collect data might have caused some errors in estimation. Thirdly, the study sample included a much higher number of females than males.

Identifying the population groups that are most exposed to risk behaviors and behaviors for NCDs (such as sedentary lifestyle) is critical for the design and implementation of actions aimed at reducing their incidence.

\section{Collaborations}

LZ Monteiro collaborated in the conception and design, data interpretation, article writing, and final approval. AR Varela collaborated in data analysis and interpretation, article writing, and final approval. BA Lira, SB Rauber, and JOT Nóbrega collaborated on article writing and final review. MS Spinola and MLA Carneiro collaborated in data collection and article writing. FB Junior collaborated in data interpretation, article writing, and final approval.

\section{Conclusion}

Our results show that a large proportion of students are adopting unhealthy lifestyles, with high use of alcohol and tobacco, inadequate eating habits, and physical activity levels below the recommended international guidelines.

There is, therefore, an urgent need for both a formulation and implementation of public health policies to promote health and improve student quality of life. Healthcare students are future health care providers, and as such will be capable of providing better care to patients when they themselves adopt better self-care behaviors and promote their own well-being.

\section{References}

1. Kumar S, Ray S, Roy D, Ganguly K, Dutta S, Mahapatra T, Mahapatra S, Gupta K, Chakraborty K, Das MK, Guha S, Deb PK, Banerjee AK. Exercise and eating habits among urban adolescents: a cross-sectional study in Kolkata, India. BMC Public Health 2017; 17:468.

2. World Health Organization (WHO). Global status report on noncommunicable diseases 2014. Geneva: WHO; 2014.

3. Malta DC, Silva Jr JB. O plano de ações estratégicas para o enfrentamento das doenças crônicas não transmissíveis no Brasil e a definição das metas globais para o enfrentamento dessas doenças até 2025: uma revisão. Epidemiol Serv Saude 2013; 22(1):151-164.

4. Brito BJQ, Gordia AP, Quadros TMB. Revisão da literatura sobre o estilo de vida de estudantes universitários. Rev Bras Qual Vida 2014; 6: 66-76.

5. Silva DAS, Pereira IMM, Almeida MB, Silva RJS, Oliveira ACC. Estilo de vida de acadêmicos de educação física de uma universidade pública do estado de Sergipe, Brasil. Rev Bras Med Esporte 2012; 34: 53-67.

6. Rombaldi AJ, Silva MC, Dumith SC, Viana VR, Hallal PC. Fatores de risco para doenças crônicas não transmissiveis em estudantes de educação física ingressantes e formandos. Rev Bras Cien Esporte 2014;36(1):1327.

7. Sousa TF, Jos HPM, Barbosa AR. Condutas negativas de saúde em estudantes universitários. Cien Saude Coletiva 2013;18(2):3563-3575.

8. Haas AL, Smith SK, Kagan K, Jacob T. Pre-college pregaming: practices, risk factors, and relationship to other indices of problematic drinking during the transition from high school to college. Psychol Addict Behav 2012; 26(4): 931-938 
9. Gasparotto GS, Gasparotto LPR, Salles MR, Campos W. Cardiovascular risk factors in college students: comparison among sexes, undergraduation period and study areas. Medicina (Ribeirão Preto) 2013; 46(2):154-163.

10. Malta DC, Silva MMA, Albuquerque GM, Lima CM, Cavalcante T, Jaime PC, Júnior JBS. A implementação das prioridades da Política Nacional de Promoção da Saúde, um balanço, 2006 a 2014. Cien Saude Colet 2014; 19(11):4301-4311.

11. Yeravdekar RC, Yeravdekar VR. Healthcare Delivery Systems at Higher Educational Institutions in India. Int J Prev Med 2014; 5: 1203-1209.

12. Luiz RR, Magnanini MMF. A lógica da determinação do tamanho da amostra em investigações epidemiológicas. Cad Saude Colet 2000; 8(2): 9-28.

13. Brasil. Ministério da Saude (MS). Secretaria de Vigilância em Saúde. Vigitel Brasil: vigilância de fatores de risco e proteção para doenças crônicas por inquérito telefônico. Brasília: MS; 2014.

14. Associação Brasileira de Empresas de Pesquisa (ABEP). Critério de classificação econômica Brasil. São Paulo: ABEP; 2016.

15. World Health Organization (WHO). Global recommendations on physical activity for health. Geneva: WHO; 2010.

16. World Health Organization (WHO). Obesity:preventing and managing the global epidemic. Geneva: WHO; 2000.

17. Colares V, Franca C, Gonzales E. Condutas de saúde entre universitários: diferença de gêneros. Cad Saude Publica 2009; 25(3): 521-528.

18. Almeida A, Beraldo CL, Magalhães EF, Lima JPR, Guimarães ML, Risso W. Tabagism and its relation with social background, sports and use of alcohol and coffee among students at Vale do Sapucaí University, Pouso Alegre, State of Minas Gerais, Brazil. Rev Med Minas Gerais 2011; 21(2):168-173.

19. Botelho C, Silva AMP, Melo CD. Tabagismo em universitários de ciências da saúde: prevalência e conhecimento. J Bras Pneumol 2011;37(3):360-366.

20. Menezes AMP, Hallal PC, Silva F. Tabagismo em estudantes de Medicina: tendências temporais e fatores associados. J Bras Pneumologia 2014; 30(3):223-228.

21. Werneck FA, Souza NE, Cartier LCM, Lourenço C, Delgado PNM, Menezes C. Prevalência do tabagismo entre os estudantes de Medicina da Universidade Severino Sombra. Rev Saude 2016; 7(2):8-11.

22. Sousa LG, Martins MCC, Andrade FT, Filho MDS, Assis RC, Santos TL, Carvalho ILNF, Veras AB, Oliveira GP. Prevalência e Fatores associados ao tabagismo entre estudantes universitários. ConScientiae Saúde 2012; 11(1):17-23.

23. Santos KP, Rodrigues A, Reinaldo MAS. Nursing students' academic training and their perception of smoking. Rev Eletr Enferm 2007; 9(2):432-442.

24. Smith DR, Leggat PA. An international review of tobacco smoking among medical students. J Postgrad Med 2007; 53(1):55-62.

25. Maciel MED, Vargas D. Alcohol consumption among nursing students. Rev Fund Care 2017; 9(1):64-70.

26. Newbury-Birch D, White M, Kamali F. Factors influencing alcohol and illicit drug use amongst medical students. Drug Alcohol Depend 2000; 59(1):125-30.
27. Mammas IN, Bertsias GK, Linardakis M, Tzanakis NE, Labadarios DN, Kafatos AG. Cigarette smoking, alcohol consumption, and serum lipid profile among medical students in Greece. Eur J Public Health 2003; 13:278-282.

28. Rombaldi AJ, Silva MC, Dumith SC, Viana VR, Hallal PC. Fatores de risco para doenças crônicas não transmissíveis em estudantes de Educação Física ingressantes e formandos. Rev Bras Cien Esporte 2014; 36(1):13-27.

29. Petrib MMV, Cabral PC, Arruda IKG. Estado nutricional, consumo alimentar e risco cardiovascular: um estudo em universitários. Rev Nutr 2009; 22(6):837846.

30. Peltzer K, Pengpid S. Underestimation of weight and its associated factors in overweight and obese university students from 21 low, middle and emerging economy countries. Obes Res Clin Pract 2015; 9(3):234-242.

31. Pengpid S, Peltzer K. Prevalence of overweight/obesity and central obesity and its associated factors among a sample of university students in India. Obes Res Clin Pract 2014; 8(6):e558-e570.

32. Costa LCF, Vasconcelos FAG. Prevalence and factors associated with nutritional status among female university students in Florianópolis, SC. Revista Brasileira de Cineantropometria \& Desempenho Humano 2013; 15(3):326-337.

33. Lachat C, Otchere S, Roberfroid D, Abdulai A, Seret FM, Milesevic J, Xuereb G, Candeias V, Kolsteren P. Diet and physical activity for the prevention of noncommunicable diseases in low- and middle-income countries: a systematic policy review. PLoS Med 2013;10(6):e1001465.

34. Khan ZN, Assir MZ, Shafiq M, Chaudhary AE, Jabeen A. High prevalence of preobesity and obesity among medical students of Lahore and its relation with dietary habits and physical activity. Indian J Endocrinol Metab 2016; 20(2):206-210.

35. Florindo AA, Brownson RC, Mielke GI, Gomes GA, Parra DC, Siqueira FV, Lobelo F, Simoes E.J, Ramos LR, Bracco MM, Hallal PC. Association of knowledge, preventive counseling and personal health behaviors on physical activity and consumption of fruits or vegetables in community health workers. BMC Public Health 2015; 15:344.

36. Pinho CPS, Diniz AS, Arruda IKG, Lira PIC, Cabral PC, Siqueira LAS, Filho MB. Consumo de alimentos protetores e preditores do risco cardiovascular em adultos do estado de Pernambuco. Rev Nutr 2012; 25(3):341-351.

37. Kolbe-Alexander TL, Conradie J, Lambert EV. Clustering of risk factors for non-communicable disease and healthcare expenditure in employees with private health insurance presenting for health risk appraisal: a cross-sectional study. BMC Public Health 2013; 13:1213.

Article submitted 12/11/2018

Approved 19/11/2019

Final version submitted 21/11/2019

Chief editors: Romeu Gomes, Antônio Augusto Moura da Silva 